\section{Susceptibility of Fraser, Canaan, and Nordmann Fir to Root Rot Incited by Phytophthora cactorum and Phytophthora drechsleri}

\author{
Benjamin K. Hoover ${ }^{1,3}$ and R.M. Bates ${ }^{2}$
}

AdDitionAl INDEX wORDs. Abies fraseri, Abies balsamea var. phanerolepis, Abies nordmanniana, phytophthora root rot, flooding, root disease, host resistance, host tolerance

Summary. The susceptibility of fraser fir (Abies fraseri), canaan fir (A. balsamea var. phanerolepis), and nordmann fir ( $A$. nordmanniana) to phytophthora root rot (PRR) incited by Phytophthora cactorum or P. drechslevi was assessed in two experiments in central Pennsylvania. In an 8-week greenhouse study, seedlings and transplants growing in soilless substrate were inoculated with Phytophthora in flooded and non-flooded settings. In an 8-week outdoor study conducted in raised planting boxes filled with soil, transplants were inoculated with Phytophthora species in well-drained and poorly drained soil. Based on foliar disease ratings, mortality rates, and dry shoot and root weights, differences in susceptibility to $P$. cactorum and $P$. drechslevi existed between these true fir (Abies) species. Fraser fir was very susceptible to $P$. cactorum and $P$. drechsleri. Canaan fir had strong resistance to $P$. cactorum and $P$. drechsleri in well-drained settings but was susceptible in poorly drained settings. Nordmann fir had very strong resistance to $P$. cactorum and $P$. drechsleri in both well-drained and poorly drained settings.

$\mathrm{F}$ raser fir was the most valuable cut Christmas tree species in the United States in 2009, accounting for $\$ 89.1$ million in sales for producers (U.S. Department of Agriculture, 2009). In the past two decades, demand for fraser fir has increased and consumers now consider it a premium product (Chastagner and Benson, 2000; Tompkins, 2000; Williams, 2002). This demand has resulted in production of fraser fir in sites ill-suited to the species, including poorly drained soils (Johnson, 2009; Owen, 2005). The limiting factor in fraser fir Christmas tree production on poorly drained sites is $P R R$, which may be incited by several Phytophthora species (Benson et al., 1976; Kuhlman

This research was supported in part by agricultural research funds administered by the Pennsylvania Department of Agriculture and the generous support of the Pennsylvania Christmas Tree Growers Association.

I thank Tracey Olson at the Pennsylvania Department of Agriculture Plant Disease Diagnostic Laboratory for providing the Phytophthora isolates used in this study. I also thank David Despot and Retha Sellmer for technical assistance with portions of this research.

${ }^{1}$ Graduate Research Assistant, Department of Plant Science (previously Department of Horticulture), The Pennsylvania State University, 310 Tyson Building, University Park, PA 16802

${ }^{2}$ Associate Professor of Horticulture, Department of Plant Science (previously Department of Horticulture), The Pennsylvania State University, 303 Tyson Building, University Park, PA 16802

${ }^{3}$ Corresponding author. E-mail: benjamin.k.hoover@ gmail.com. and Hendrix, 1963; Quesada-Ocampo et al., 2009; Shew and Benson, 1981). Fraser fir specimens with PRR symptoms sent to the Pennsylvania Department of Agriculture Plant Diagnostic Laboratory between 1986 and 2011 most frequently contained $P$. cactorum, P. cryptogea, or P. drechsleri (T. Olson, personal communication).

Fraser fir is considered very susceptible to PRR, with minor differences in susceptibility occurring between seed sources (Frampton and Benson, 2004). Canaan fir is closely related to fraser fir and has been reported to survive in soils conducive to PRR (Brown, 2000; Potter et al., 2010). Greenhouse and shadehouse testing of multiple seed sources of canaan fir two-year-old and three-year-old seedlings growing in soilless substrate in North Carolina found susceptibility to $P$. cinnamomi in all seed sources, although some variation in degree of susceptibility occurred (Benson et al., 1998b).
Studies conducted in North Carolina indicate variation in resistance to $P$. cinnamomi exists between true fir species as containerized seedlings in soilless substrate, with the greatest tolerance or resistance to $P$. cinnamomi being observed in momi fir $(A$. firma) and turkish fir [A. nordmanniana ssp. equi-trojani (syn. A. bornmuelleriana)] (Benson et al.,1998a; Hinesley et al., 2000). In the Benson et al. (1998a) study, nordmann fir had less severe foliar symptoms than fraser fir but was still determined to be very susceptible to $P$. cinnamomi.

Despite having considerable resistance to $P$. cinnamomi, momi fir has little potential as a cut Christmas tree crop because of its morphological features and susceptibility to spring frost damage (Hibbert-Frey et al., 2010; Hinesley and Frampton, 2002). Turkish fir is a better candidate as a cut Christmas tree crop and is considered either a natural hybrid between greek fir (A. cephalonica) and nordmann fir or a subspecies of nordmann fir (Farjon, 2010; Liu, 1971). The close relationship between turkish fir and nordmann fir suggests that nordmann fir might possess Phytophthora resistance genes. Nordmann fir is more readily available in the U.S. conifer industry than turkish fir and additional testing on its resistance to PRR-inciting Phytophthora is warranted.

This study involved testing fraser fir, canaan fir, and nordmann fir for resistance to PRR incited by $P$. cactorum or $P$. drechsleri. Inoculation tests were done in a 2009 greenhouse experiment with seedlings and transplants growing in soilless substrate and in a 2010 outdoor experiment in planting boxes containing transplants growing in soil, with a flooding treatment included to create conditions favorable for PRR.

\section{Materials and methods}

In Summer 2009, a greenhouse experiment was conducted in University

\begin{tabular}{llll}
\hline $\begin{array}{l}\text { Units } \\
\text { To convert U.S. to SI, } \\
\text { multiply by }\end{array}$ & U.S. unit & SI unit & $\begin{array}{l}\text { To convert SI to U.S., } \\
\text { multiply by }\end{array}$ \\
\hline 0.3048 & $\mathrm{ft}$ & $\mathrm{m}$ & 3.2808 \\
2.54 & inch(es) & $\mathrm{cm}$ & 0.3937 \\
16.3871 & inch & $\mathrm{cm}^{3}$ & 0.0610 \\
0.0254 & $\mathrm{mil}^{3}$ & $\mathrm{~mm}$ & 39.3701 \\
28.3495 & $\mathrm{oz}$ & $\mathrm{g}$ & 0.0353 \\
1 & $\mathrm{ppm}$ & $\mathrm{mg} \cdot \mathrm{L}^{-1}$ & 1 \\
$\left({ }^{\circ} \mathrm{F}-32\right) \div 1.8$ & ${ }^{\circ} \mathrm{F}$ & ${ }^{\circ} \mathrm{C}$ & $\left({ }^{\circ} \mathrm{C} \times 1.8\right)+32$
\end{tabular}


Park, PA (lat. $40^{\circ} 80^{\prime} \mathrm{N}$, long. $\left.77^{\circ} 86^{\prime} \mathrm{W}\right)$. On 5 May 2009 , firs purchased from a commercial grower were planted in pots $\left(656 \mathrm{~cm}^{3}\right.$ volume, D40 Deepots; Stuewe \& Sons, Tangent, OR) with a pine bark-based soilless substrate (NX-6; Frey Brothers, Quarryville, PA). The fraser (Roan Mountain provenance) and canaan fir were one-year-old seedlings in plugs, the nordmann fir were (Bakuriani provenance) two-year-old seedlings in plugs and (Bakhmaro provenance) 3- to 6-inch-tall bare-root transplants. Before potting, roots were washed to remove all existing substrate. The root systems of the fraser, canaan, and Bakuriani provenance nordmann fir seedlings were very similar in size. The Bakhmaro provenance nordmann fir transplants had larger root systems than the other seedlings. Potted plants were placed on racks (D20C Deepots, Stuewe \& Sons). Each rack contained eight pots, with $5-\mathrm{cm}$ spacing between pot edges. The racks were placed on two benches in a greenhouse. Until the conclusion of the experiment, the firs were fertilized every other week with a $280 \mathrm{mg} \cdot \mathrm{L}^{-1}$ nitrogen $(\mathrm{N})$ solution (21N-3.1P-5.8K; Scotts, Marysville, $\mathrm{OH})$. Watering was provided by hand as needed. Air temperature in the greenhouse was recorded with a sensor and data logger (HOBO Pendant; Onset, Cape Cod, MA) suspended $1 \mathrm{~m}$ above one of the benches during the experiment.

Isolates of $P$. cactorum [Phytophthora Database ID: PD_00551 (Kang, 2012a)] and P.drechsleri [PD_00640 (Kang, 2012b)] from dead fraser fir seedlings were obtained from the Pennsylvania Department of Agriculture Plant Diagnostic Laboratory. Inoculum was cultured on long grain rice (Oryza sativa) following the methods described by Hoover (2012). Firs were inoculated on 30 May 2009 with $0.5 \mathrm{~g}$ of rice sprinkled on the media surface of each pot. The Phytophthora negative control consisted of noninfested rice that had been autoclaved. The factors in addition to fir species were Phytophthora (absent, P. cactorum, or $P$. drechsleri) and flooding (absent or $24 \mathrm{~h}$ /week), for a total of 24 treatment combinations. Each treatment combination had 20 replicates, resulting in 480 plants in the experiment. Treatments were assigned randomly. Flooding treatments began on 1 June 2009. Each pot to be flooded was wrapped in plastic and then watered until $\approx 2 \mathrm{~cm}$ of standing water covered the substrate surface. Weekly foliar disease ratings, adapted from top ratings used by Hinesley et al. (2000), were recorded. The ratings were as follows: 1 = healthy, 2 = slightly chlorotic, 3 = severely necrotic, and 4 = dead. The first data collection occurred on 30 May 2009, and the experiment ran for 8 weeks. Weekly plant mortality was recorded with dead plants recorded as $\mathrm{l}$ and live plants 0 to provide a proportion of mortality. At the conclusion of the experiment, shoots and roots were oven dried at $150^{\circ} \mathrm{F}$ for 1 week, then weighed. Before drying, roots were plated on semiselective media to isolate Phytophthora using the methods described by Hoover (2012). Morphological identification of the isolated Phytophthora was done under a microscope using the key of Gallegly and Hong (2008).

An outdoor planting box experiment was conducted during Summer 2010 at the Russell E. Larson Agriculture Research Center at Rock Springs in Pennsylvania Furnace, PA (lat. $40^{\circ} 42^{\prime} \mathrm{N}$, long. $77^{\circ} 56^{\prime} \mathrm{W}$ ). On 25 May 2010, fir transplants purchased from a commercial grower were planted in 32 boxes 36 inches by 33 inches by 11.25 inches (volume 13,365 inches ${ }^{3}$ ) with Hagerstown silt loam, which contained enough subsoil to be classified as a clay loam. The fraser fir (Roan Mountain provenance) were bare root plug $+1+1$ transplants (plug plus one year in a transplant bed plus one year in another transplant bed), the canaan fir were bare root plug +1.5 (plug plus 1.5 years in a transplant bed) transplants, and the nordmann fir (Apsheronsk provenance) were bare root plug $+1+1$ transplants. The transplants were very uniform in size within and between species. Ten plants of each species were randomly assigned to three rows in each box, with 3 -inch spacing within rows and 8 -inch spacing between rows. Flooded treatment boxes were lined with a double layer of 6-mil clear plastic. The soil was kept above field capacity and at or very near saturation at all times during the experiment. When the water level exceeded $2 \mathrm{~cm}$ above the soil surface, a siphon was used to drain off excess. Two spray stakes in each box provided $\approx 2 \mathrm{~cm}$ of water daily for non-flooded boxes.
The rate of water supplied to flooded boxes was reduced after the soil reached saturation to reduce the amount of standing water above the soil surface.

The experimental design was a randomized complete block with four blocks. Each box received one combination of the following factors: $P$. cactorum (absent, present), P. drechsleri (absent, present), and flooding (absent, present). Phytophthora inoculum was produced using the same method as mentioned earlier in the greenhouse study and applied on 7 June 2010. The P. cactorum and $P$. drechsleri absent treatments consisted of noninfested autoclaved rice. Each plant received $0.5 \mathrm{~g}$ of rice from one of the $P$. cactorum and one of the $P$. drechsleri treatments sprinkled on the soil surface within a $2-\mathrm{cm}$ radius of the stem.

Weekly foliar disease ratings were recorded. The scale was adjusted from the four point scale used in 2009 to a 5-point scale based on percentage of foliar necrosis: $\mathrm{l}=$ healthy (no necrosis), $2=$ mild symptoms ( $1 \%$ to $33 \%$ necrosis), $3=$ moderate symptoms (34\% to $67 \%$ necrosis), $4=$ severe symptoms (68\% to $99 \%$ necrosis), $5=$ dead $(100 \%$ necrosis $)$. The experiment ran for 8 weeks, with the final rating recorded on 2 Aug. 2010. Weekly plant mortality was recorded as a proportion of each fir species in each box that had died. A weather station at the Russell E. Larson Agriculture Research Center provided air temperature and precipitation data during the experiment. At the conclusion of the experiment, Phytophthora isolations from root samples were conducted using the plating techniques mentioned earlier.

Data from foliar disease ratings at the conclusion of the 2009 experiment were analyzed with a Model I (fixed factor) analysis of variance (ANOVA) using PROC GLM in SAS (version 9.3; SAS Institute, Cary, $\mathrm{NC}$ ). The 2010 foliar disease ratings data from the conclusion of the experiment were analyzed with a MODEL III (mixed-model) ANOVA using PROC MIXED with blocks treated as a random factor. Residual plots were generated to confirm that the assumptions of ANOVA were met. Residuals of the response variable were normally distributed, and the variances of the response variable were equal. Multiple 
comparisons were conducted with PROC GLIMMIX using an adjusted Tukey's Studentized range test with slice statements. Mortality data were analyzed with a repeated measures statement in PROC GLIMMIX with an autoregressive covariance structure; multiple comparisons were done with an adjusted Tukey's Studentized range test. Dry weight of shoots and roots from the 2009 experiment were separated by true fir species and analyzed with PROC GLM, followed by multiple comparisons in PROC GLIMMIX with an adjusted Tukey's Studentized range test. The significance level $(\alpha)$ used to reject null hypotheses for all statistical tests was set at 0.05 .

\section{Results and discussion}

Interactions between factors in the 2009 experiment preclude the discussion and analysis of main effects (Table 1). Fraser fir had a higher foliar disease rating than canaan fir and nordmann fir when exposed to $P$. cactorum in both non-flooded and flooded conditions (Table 2). Fraser fir also had higher foliar disease ratings than canaan fir and nordmann fir when exposed to either Phytophthora species in non-flooded conditions (Table 2). When flooding was added to the $P$. drechsleri treatment, fraser fir and canaan fir had the same foliar disease rating, which was higher than that of nordmann fir (Table 2). When flooded, all fraser fir had the same high foliar disease rating regardless of Phytophthora treatment (Table 2). Canaan fir had the same low foliar disease rating in all non-flooded Phytophthora treatments (Table 2). Flooding with exposure to $P$. cactorum or $P$. drechsleri resulted in increased foliar disease ratings in canaan fir compared with the non-flooded $P$. cactorum and P. drechsleri treatments (Table 2). Nordmann fir remained healthy regardless of flooding or Phytophthora treatments (Table 2 ).

Plant mortality began to show differences between fir species in week 4 of the 2009 experiment [Fig. 1

Table 1. Analysis of variance for foliar disease ratings ${ }^{\mathrm{z}}$ of true fir transplants exposed to Phytophthora species and flooding treatments, 2009.

\begin{tabular}{lcrr}
\hline Effect & df & $\boldsymbol{F}$ & \multicolumn{1}{c}{$\boldsymbol{P}$} \\
\hline True fir $^{\mathrm{y}}$ & 3 & 141.44 & $<0.0001$ \\
Flooding $^{\mathrm{x}}$ & 1 & 70.76 & $<0.0001$ \\
Phytophthora $^{\mathrm{w}}$ & 2 & 28.72 & $<0.0001$ \\
True fir $\times$ flooding & 3 & 20.08 & $<0.0001$ \\
True fir $\times$ Phytophthora & 6 & 9.05 & $<0.0001$ \\
Flooding $\times$ Phytophthora & 2 & 1.48 & 0.2289 \\
True fir $\times$ flooding $\times$ Phytophthora & 6 & 5.53 & $<0.0001$ \\
\hline
\end{tabular}

${ }^{\mathrm{z}} 1$ = healthy, 2 = slightly chlorotic, 3 = severely necrotic, 4 = dead

Fraser fir, canaan fir, nordmann fir.

${ }^{x}$ Flooding levels: absent, present $(24 \mathrm{~h} /$ week $)$.

${ }^{w}$ Phytophthora levels: absent (0.5-g noninfested rice), P. cactorum (0.5-g infested rice), P. drechsleri (0.5-g infested rice); $\mathrm{lg}=0.0353 \mathrm{oz}$.

Table 2. True fir foliar disease rating least squares (LS) means at the conclusion of the experiment after exposure to Phytophthora species and flooding treatments, 2009.

\begin{tabular}{llllcc}
\hline & & \multicolumn{4}{c}{ Foliar disease ratings ${ }^{\mathrm{z}}$ (LS means) } \\
\cline { 3 - 6 } & $\begin{array}{c}\text { Phytophthora } \\
\text { treatment }\end{array}$ & Fraser fir & Canaan fir & $\begin{array}{c}\text { Nordmann fir } \\
\text { (Bakhmaro) }\end{array}$ & $\begin{array}{c}\text { Nordmann fir } \\
\text { (Bakuriani) }\end{array}$ \\
\hline Non-flooded & Control & $1.0 \mathrm{a}^{\mathrm{y}} \mathrm{A}^{\mathrm{x}}$ & $1.1 \mathrm{a} \mathrm{A}$ & $1.0 \mathrm{a} \mathrm{A}$ & $1.0 \mathrm{a} \mathrm{A}$ \\
& P. cactorum & $3.5 \mathrm{c} \mathrm{B}$ & $1.2 \mathrm{a} \mathrm{A}$ & $1.3 \mathrm{a} \mathrm{A}$ & $1.2 \mathrm{a} \mathrm{A}$ \\
& P. drechsleri & $2.6 \mathrm{~b} \mathrm{~B}$ & $1.0 \mathrm{a} \mathrm{A}$ & $1.0 \mathrm{a} \mathrm{A}$ & $1.0 \mathrm{a} \mathrm{A}$ \\
Flooded $^{\mathrm{w}}$ & Control & $3.1 \mathrm{bc} \mathrm{B}$ & $1.6 \mathrm{ab} \mathrm{A}$ & $1.0 \mathrm{a} \mathrm{A}$ & $1.1 \mathrm{a} \mathrm{A}$ \\
& P. cactorum & $4.0 \mathrm{c} \mathrm{C}$ & $2.3 \mathrm{bc} \mathrm{B}$ & $1.3 \mathrm{a} \mathrm{A}$ & $1.5 \mathrm{a} \mathrm{AB}$ \\
& P. drechsleri & $3.6 \mathrm{c} \mathrm{B}$ & $2.9 \mathrm{c} \mathrm{B}$ & $1.0 \mathrm{a} \mathrm{A}$ & $1.0 \mathrm{a} \mathrm{A}$ \\
\hline
\end{tabular}

${ }^{\mathrm{z}} 1$ = healthy, 2 = slightly chlorotic, 3 = severely necrotic, 4 = dead.

${ }^{y}$ LS means within a column with the same lowercase letter are not different according to an adjusted Tukey's Studentized range test at $P \leq 0.05$.

${ }^{x}$ LS means within a row with the same uppercase letter are not different according to an adjusted Tukey's Studentized range test at $P \leq 0.05$.

"Flooding treatment: $2 \mathrm{~h} /$ week.
$(P \leq 0.05)]$. Differences between true fir species in the mortality data were very similar to the foliar disease ratings. In the flooded $P$. cactorum treatment and in the flooded P. drechsleri treatment, a gradient of mortality existed from week 6 to the end of the experiment, with fraser fir having the highest mortality rate, canaan fir having a lower rate, and nordmann fir having the lowest mortality rate [Fig. 1 $(P \leq 0.05)]$.

Dry root weight of fraser fir was reduced when flooding or Phytophthora treatments were present $(P<0.0001)$, with the lowest weights in the $P$. cactorum treatment with or without flooding and the flooded $P$. drechsleri treatment (Fig. 2). Both canaan fir and nordmann fir of Bakuriani provenance had the lowest root weights in the flooded Phytophthora treatments (Fig. 2). Dry shoot data followed a similar pattern, though no differences between treatments existed for nordmann fir (Fig. 2). More differences in root and shoot dry weights between treatments may have been observed if the duration of the experiment was extended.

Fraser fir inoculated with Phytophthora had severely diseased roots at the conclusion of the 2009 experiment. Canaan fir inoculated with Phytophthora had little root disease in non-flooded treatments but moderate to severe disease in flooded treatments. Nordmann fir inoculated with Phytophthora had little root disease in non-flooded or flooded treatments. Both $P$. cactorum and $P$. drechsleri were recovered from inoculated fraser fir and canaan fir roots. No Phytophthora were isolated from plated nordmann fir roots.

In the 2009 greenhouse experiment, fraser fir was highly susceptible to $P$. cactorum and P. drechsleri based on foliar disease ratings and dry tissue weights. Canaan fir showed resistance to $P$. cactorum and $P$. drechsleri in non-flooded conditions, though in flooded conditions some susceptibility occurred. Nordmann fir was very resistant to $P$. cactorum and $P$. drechsleri. The differences between nordmann fir provenances observed in foliar disease ratings and root dry weights after exposure to flooded Phytophthora treatments may be a reflection of differences in sizing or preconditioning since the Bakuriani plants were seedlings and the Bakhmaro 

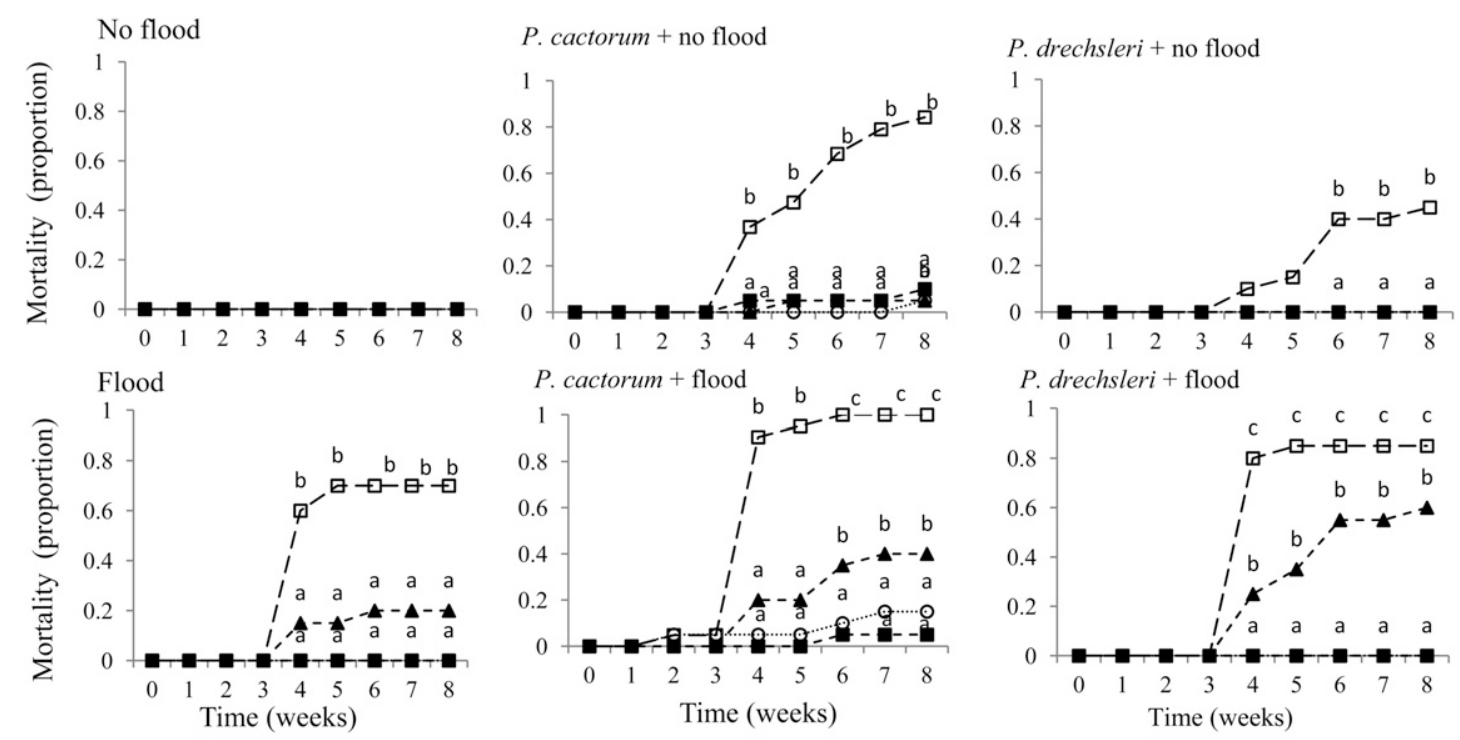

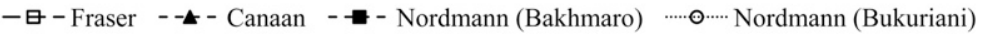

Fig. 1. True fir mortality over time in transplants exposed to Phytophthora treatments and flooding, 2009. Flooding treatment = weekly $24 \mathrm{~h}$ periods of saturation. Weekly mortality least squares means of fir species under each treatment with the same letter are not different according to an adjusted Tukey's Studentized range test $(P \leq 0.05)$.
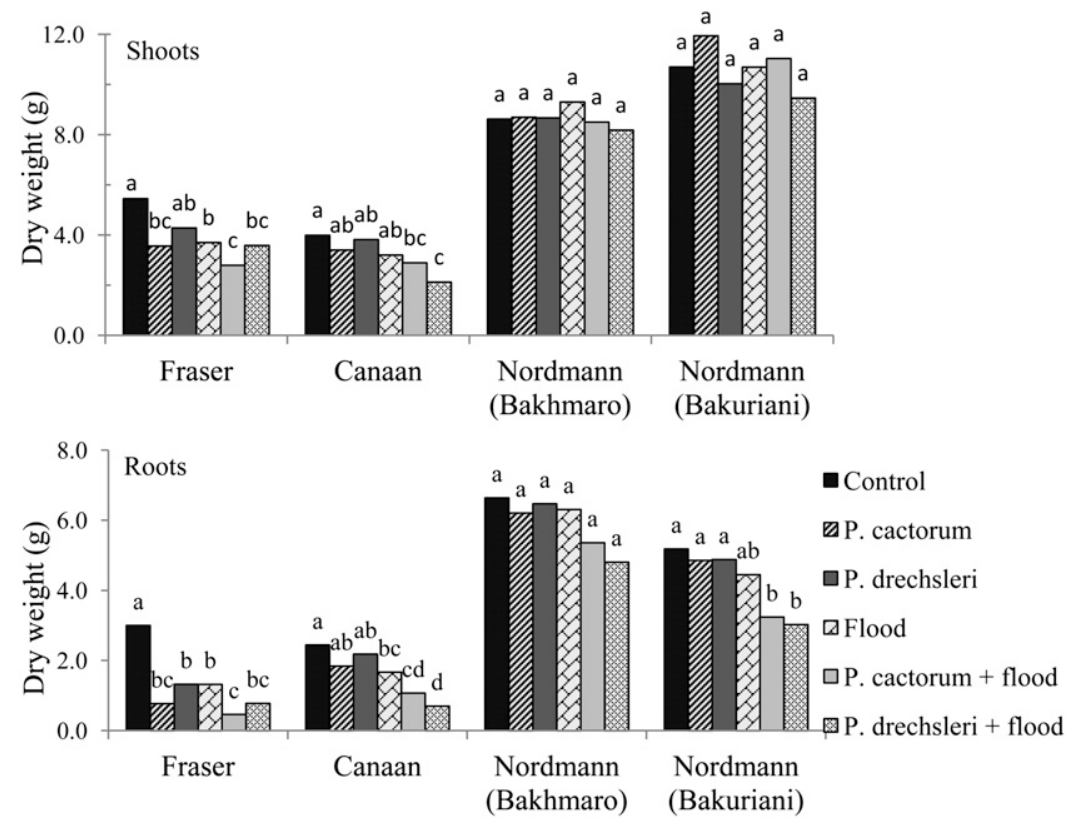

Fig. 2. True fir shoot and root dry weight least squares (LS) means in grams at the conclusion of the experiment after exposure to Phytophthora cactorum, P. drechsleri, and flooding treatments. LS mean totals in each fir species with the same letter are not different according to an adjusted Tukey's Studentized range test $(P \leq 0.05)$; $1 \mathrm{~g}=0.0353 \mathrm{oz}$.

plants were transplants. The difference in plant age and size between the nordmann fir (two-year-old seedlings or 3- to 6-inch transplants) and the fraser fir and canaan fir (one-year-old seedlings) may have been a complicating factor in the experiment.

In the 2010 experiment, differences in foliar disease ratings were found between treatments (Table 3 ). Canaan fir and nordmann fir had the same foliar disease rating regardless of flooding, whereas fraser fir had a higher disease rating when flooded than when not flooded $(P<0.0001)$. Fraser fir and canaan fir had higher foliar disease ratings when exposed to $P$. cactorum than when not exposed to $P$. cactorum, whereas nordmann fir had the same foliar disease ratings regardless of exposure to $P$. cactorum $(P=0.0154)$. Fraser fir had higher foliar disease ratings when exposed to $P$. drechsleri than when not exposed to $P$. drechsleri, whereas canaan fir and nordmann fir had the same foliar disease ratings regardless of exposure to $P$. drechsleri $(P=0.0039)$.

Fraser fir had higher disease ratings than canaan fir and nordmann fir when exposed to either $P$. cactorum or $P$. drechsleri in non-flooded conditions (Table 4 ). In the flooded $P$. cactorum treatment, fraser fir and canaan fir had higher disease ratings than nordmann fir (Table 4). Differences within fir species were observed for fraser fir and canaan fir, whereas nordmann fir had no differences. Fraser fir had the lowest foliar disease rating in the non-flooded treatment with no Phytophthora, and all flooded treatments were the same with higher foliar disease ratings (Table 4). Canaan fir showed a split based on flooding treatment. All non-flooded treatments were the same, while all the flooded treatments were the same and had higher foliar disease ratings than the non-flooded treatments (Table 4).

Mortality rates of canaan fir and nordmann fir were the same in all non-flooded Phytophthora treatments, whereas fraser fir had higher mortality 
Table 3. Analysis of variance for foliar disease ratings ${ }^{\mathrm{z}}$ of true fir transplants exposed to Phytophthora species and flooding treatments, 2010.

\begin{tabular}{|c|c|c|c|}
\hline Effect & df & $F$ & $P$ \\
\hline True fir ${ }^{y}$ & 2 & 330.49 & $<0.0001$ \\
\hline Flooding ${ }^{x}$ & 1 & 345.56 & $<0.0001$ \\
\hline P. cactorum $^{\mathrm{w}}$ & 1 & 28.09 & $<0.0001$ \\
\hline P. drechsleri ${ }^{\mathrm{w}}$ & 1 & 15.85 & 0.0002 \\
\hline P. cactorum $\times$ P. drechsleri & 1 & 2.59 & 0.1123 \\
\hline True fir $\times$ flooding & 2 & 41.92 & $<0.0001$ \\
\hline True fir $\times P$. cactorum & 2 & 4.44 & 0.0154 \\
\hline True fir $\times P$. drechsleri & 2 & 6.01 & 0.0039 \\
\hline Flooding $\times P$. cactorum & 1 & 12.67 & 0.0007 \\
\hline Flooding $\times P$. drechsleri & 1 & 5.02 & 0.0282 \\
\hline True fir $\times$ flooding $\times P$. cactorum & 2 & 4.26 & 0.0180 \\
\hline True fir $\times$ flooding $\times P$. drechsleri & 2 & 3.87 & 0.0254 \\
\hline True fir $\times P$. cactorum $\times P$. drechsleri & 2 & 1.96 & 0.1493 \\
\hline True fir $\times$ flooding $\times P$. cactorum $\times P$. drechsler $i$ & 3 & 1.27 & 0.2914 \\
\hline
\end{tabular}

${ }^{2} 1$ = healthy (no necrosis), 2 = mild symptoms ( $1 \%$ to $33 \%$ necrosis), 3 = moderate symptoms ( $34 \%$ to $67 \%$ necrosis), 4 = severe symptoms ( $68 \%$ to $99 \%$ necrosis), $5=$ dead ( $100 \%$ necrosis)

y Fraser fir, canaan fir, nordmann fir.

${ }^{x}$ Flooding levels: absent, present (soil continually near saturation).

${ }^{w} P$. cactorum and $P$. drechsleri treatments: present ( 0.5 -g infested rice) and absent (0.5-g noninfested rice); $1 \mathrm{~g}=$ $0.0353 \mathrm{oz}$

Table 4. True fir foliar disease rating least squares (LS) means at the conclusion of the experiment after exposure to Phytophthora species and flooding treatments, 2010.

\begin{tabular}{|c|c|c|c|c|}
\hline & \multirow[b]{2}{*}{ Phytophthora treatment } & \multicolumn{3}{|c|}{ Foliar disease ratings ${ }^{\mathrm{z}}$ (LS means) } \\
\hline & & Fraser & Canaan & Nordmann \\
\hline \multirow[t]{4}{*}{ Non-flooded } & Control & $1.6 \mathrm{a}^{\mathrm{y}} \mathrm{A}^{\mathrm{x}}$ & $1.2 \mathrm{a} \mathrm{A}$ & 1.1 a $\mathrm{A}$ \\
\hline & P. cactorum & $3.3 \mathrm{~b} \mathrm{~B}$ & $2.0 \mathrm{a} \mathrm{A}$ & $1.2 \mathrm{a} A$ \\
\hline & P. drechsleri & $3.3 \mathrm{~b} \mathrm{~B}$ & $1.5 \mathrm{a} \mathrm{A}$ & $1.2 \mathrm{a} \mathrm{A}$ \\
\hline & Both & $4.1 \mathrm{bc} \mathrm{B}$ & 2.1 a $\mathrm{A}$ & 1.5 a $\mathrm{A}$ \\
\hline \multirow[t]{4}{*}{ Flooded $^{\mathrm{w}}$} & Control & $4.7 \mathrm{~cd} \mathrm{C}$ & $3.3 \mathrm{~b} \mathrm{~B}$ & 1.8 a $\mathrm{A}$ \\
\hline & P. cactorum & $4.8 \mathrm{~cd} \mathrm{~B}$ & $4.1 \mathrm{~b} \mathrm{~B}$ & 1.7 a $\mathrm{A}$ \\
\hline & P. drechsleri & $5.0 \mathrm{~d} \mathrm{C}$ & $4.0 \mathrm{~b} \mathrm{~B}$ & 1.7 a A \\
\hline & Both & $5.0 \mathrm{~d} \mathrm{C}$ & $3.9 \mathrm{~b} \mathrm{~B}$ & 1.7 a A \\
\hline
\end{tabular}

${ }^{2}$ Foliar disease ratings scale: 1 = healthy (no necrosis), 2 = mild symptoms ( $1 \%$ to $33 \%$ necrosis), 3 = moderate symptoms ( $34 \%$ to $67 \%$ necrosis), $4=$ severe symptoms ( $68 \%$ to $99 \%$ necrosis), $5=$ dead ( $100 \%$ necrosis).

y $\mathrm{LS}$ means within a column with the same lowercase letter are not different according to an adjusted Tukey's Studentized range test at $P \leq 0.05$.

${ }^{x}$ LS means within a row with the same uppercase letter are not different according to an adjusted Tukey's Studentized range test at $P \leq 0.05$

"Flooding levels: absent, present (soil continually near saturation).

rates. Under flooded conditions, exposure to Phytophthora resulted in a similar gradient of true fir mortality as seen in the 2009 study, with fraser fir having the highest mortality, canaan fir having lower mortality, and nordmann fir having the lowest mortality (Fig. 3).

In the 2010 outdoor planting box experiment, fraser fir was highly susceptible to $P$. cactorum and $P$. drechsleri. Canaan fir was resistant to $P$. cactorum and $P$. drechsleri under non-flooded conditions but was susceptible under flooded conditions. Nordmann fir was highly resistant to $P$. cactorum and $P$. drechsleri in flooded and non-flooded conditions. Root plating resulted in recovery of both species of Phytophthora from fraser fir and canaan fir roots, whereas no Phytophthora were recovered from nordmann fir roots. Nordmann fir had diseased roots with severe discoloration and loss of structural integrity in the flooded treatments but no Phytophthora were isolated from those roots.

In these two inoculation experiments, canaan fir showed strong resistance to PRR incited by P. cactorum or P. drechsleri in non-flooded settings and more resistance to PRR in flooded settings than fraser fir. This resistance to $P$. cactorum and $P$. drechsleri in non-flooded conditions is considerably higher than the resistance of canaan fir to $P$. cinnamomi observed by Benson et al. (1998b). The heavy watering that occurred in the Benson et al. (1998b) experiments was not as severe as the flooding treatments used in this study, yet produced similar results. The level of soil moisture or duration of flooding at which canaan fir becomes susceptible to $P$. cactorum or P. drechsleri is not known. This is of critical importance in determining the suitability of canaan fir for use in production sites with poorly drained soils. Canaan fir is very variable in morphological traits and postharvest needle retention (Bates et al., 2004) and shows some differences in susceptibility to $P$. cinnamomi between seed sources (Benson et al., 1998b). With selection for tolerance of poorly drained soils and resistance to PRR, canaan fir could allow true fir production on sites not suited for fraser fir.

Nordmann fir showed strong resistance to $P$. cactorum and $P$. drechsleri in these inoculation experiments. Benson et al. (1998a) reported susceptibility of nordmann fir to PRR incited by $P$. cinnamomi. The resistance to PRR incited by $P$. cactorum or $P$. drechsleri observed in this study may be a result of differences in virulence of Phytophthora species to nordmann fir, genetic and phenotypic variation in the nordmann fir used in the studies, or differences in environmental conditions. Phytophthora cactorum and $P$. drechsleri have broad host ranges but are known to have differences in pathogenicity to different hosts (Chastagner, 2001; Erwin and Ribeiro, 1996). Nordmann fir has been reported susceptible to a Phytophthora species similar to P. inundata in Norway (Talgø et al., 2007), and in Hungary, a Phytophthora species lacking a name consistent with nomenclatural rules (currently referred to as $P$. niederbauserii) has been reported to cause sporadic disease in nordmann fir in a nursery setting (Józsa, et al., 2010). Nordmann fir is known to be variable in morphological and postharvest traits (Madsen, 1994; Nielsen and Chastagner, 2005), resistance to Phytophthora may also be a variable trait.

Although nordmann fir showed strong resistance to PRR in this study, the length of time the plants were 

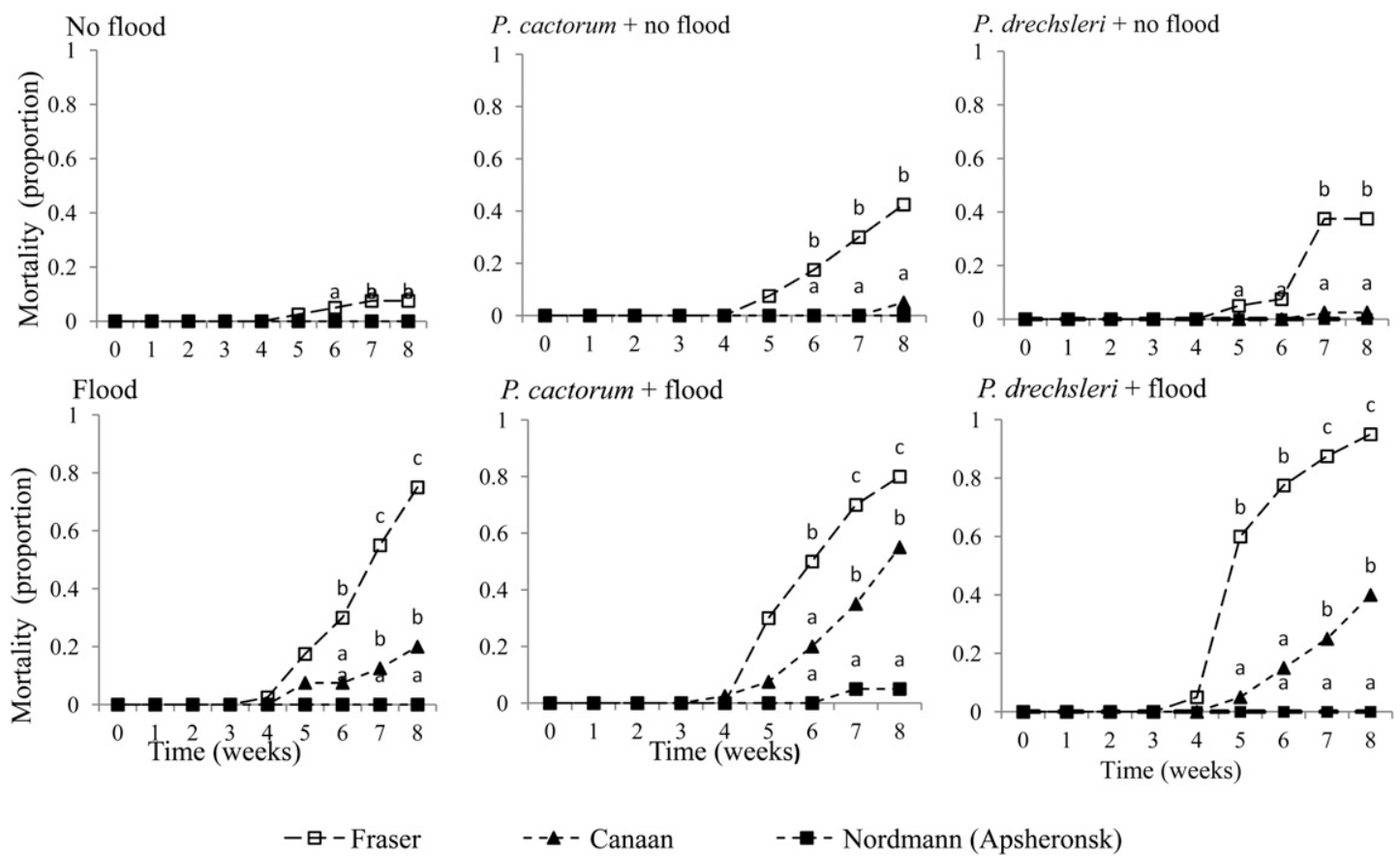

Fig. 3. True fir mortality over time in transplants exposed to Phytophthora treatments and flooding, 2010. Weekly mortality means between fir species within treatments with the same letter are not different according to an adjusted Tukey's Studentized range test $(P \leq 0.05)$. Flooding treatment $=$ continuous soil moisture near saturation.

under study was limited to a portion of one growing season. Environmental conditions during these experiments were favorable for PRR development. Substrate or soil saturation occurred to promote the release of zoospores. Soil temperatures were in the active range of $P$. cactorum and $P$. drechsleri, with considerable time near the optimal temperature of $25^{\circ} \mathrm{C}$ for P. cactorum (Erwin and Ribeiro, 1996). Questions remain regarding the longterm effect of exposure to PRR on survival, growth rate, and development of nordmann fir. In addition, questions also exist about the growth rate and hardiness of nordmann fir in Christmas tree production in the eastern United States (Jones and Cregg, 2006). Nordmann fir is a popular Christmas tree crop in Europe (Chastagner and Benson, 2000), but the response of consumers in the eastern United States to differences in branch and needle morphology between nordmann fir and fraser fir is not known.

Applying results of true fir levels of resistance to Phytophthora species observed in greenhouse and box studies to field outcomes must be done with caution. In production settings, many variables could lead to reduction in the resistance observed in this study, including exposure to other species or isolates of Phytophthora not tested in this study and environmental conditions that are more favorable to disease.

\section{Literature cited}

Bates, R.M., J.C. Sellmer, and D.A. Despot. 2004. Postharvest characteristics of canaan fir and fraser fir Christmas trees. HortScience 39(7):1674-1676.

Benson, D.M., L.F. Grand, and E.G. Suggs. 1976. Root rot of fraser fir caused by Phytophthora drechsleri. Plant Dis. Rptr. 60(3):238-240.

Benson, D.M., L.E. Hinesley, J. Frampton, and K.C. Parker. 1998a. Evaluation of six Abies spp. to phytophthora root rot caused by Phytophthora cinnamomi. Biol. Cult. Tests Control Plant Dis. 13:57.

Benson, D.M., L.E. Hinesley, and K.C. Parker. 1998b. Evaluation of canaan seed sources for resistance to phytophthora root rot caused by Phytophthora cinnamomi. Biol. Cult. Tests Control Plant Dis. 13:58.

Brown, J.H. 2000. Survival and growth of trees of a Canaan Valley, West Virginia, seed source in relation to varying soil/site conditions. Ohio State Univ. Ext. Spec. Circ. 175-00.

Chastagner, G.A. 2001. Fir diseases, p. 152-156. In: R.K. Jones and D.M. Benson (eds.). Diseases of woody ornamentals and trees in nurseries. APS Press, St. Paul, MN.

Chastagner, G.A. and D.M. Benson. 2000. The Christmas tree: Traditions, production and diseases. Plant Health Prog., doi: 10.1094/PHP-2000-1013$01-2 \mathrm{~V}$.

Erwin, D.C. and O.K. Ribeiro. 1996. Phytophthora diseases worldwide. APS Press, St. Paul, MN.

Farjon, A. 2010. A handbook of the world's conifers. Vol. I. Brill, Leiden, The Netherlands.

Frampton, J. and D.M. Benson. 2004. Phytophthora root rot mortality in fraser fir seedlings. HortScience 39(5):10251026.

Gallegly, M.E. and C. Hong. 2008. Phytophthora: Identifying species by morphology and DNA fingerprints. APS Press, St. Paul, MN.

Hibbert-Frey, H., J. Frampton, F.A. Blazich, and L.E. Hinesley. 2010. Grafting fraser fir (Abies fraseri): Effect of grafting date, shade, and irrigation. HortScience 45(4):617-620.

Hinesley, E. and J. Frampton. 2002. Grafting fraser fir onto rootstocks of selected Abies species. HortScience 37(5): 815-818.

Hinesley, L.E., K.C. Parker, and D.M. Benson. 2000. Evaluation of seedlings of fraser, momi, and siberian fir for resistance 
to Phytophthora cinnamomi. HortScience 35(1):87-88.

Hoover, B.K. 2012. Fungicide efficacy in prevention of root rot incited by Phytophthora cactorum and Phytophthora drechsleri in fraser fir seedlings. Hort Technology 22(4):470-475.

Johnson, J.E. 2009. Species for Christmas tree planting in Virginia. Virginia Coop. Ext. Virginia Polytechnic Inst. State Univ. 420-082.

Jones, G.E. and B.M. Cregg. 2006. Budbreak and winter injury in exotic firs. HortScience 41(1):143-148.

Józsa, A., J. Bakonyi, L. Belbahri, Z.Á. Nagy, A. Szigethy, G. Bohár, and S. Woodward. 2010. A new species of Phytophthora reported to cause root and collar rot of common boxwood, nordmann fir and port orford cedar in Hungary. Plant Pathol. 59(6):1166-1167.

Kang, S. 2012a. Phytophthora database: Isolate browser: PD_00551.31 Mar. 2012. <http://www.phytophthoradb.org/ isolate. $p h p ? a=d v \& i d=551 \& p=17 \& 1=30 \&$ $\mathrm{sv}=\& \mathrm{sf}=>$.
Kang, S. 2012b. Phytophthora database: Isolate browser: PD_00640.31 Mar. 2012. <http://www.phytophthoradb.org/ isolate.php? $\mathrm{a}=\mathrm{dv} \& \mathrm{id}=640 \& \mathrm{p}=3 \& \mathrm{l}=30 \&$ $\mathrm{sv}=\& \mathrm{sf}=>$.

Kuhlman, E.G. and F.F. Hendrix, Jr. 1963. Phytophthora root rot of fraser fir. Plant Dis. Rptr. 47(6):552-553.

Liu, T.S. 1971. A monograph of the genus Abies. National Taiwan Univ., Taipei, Taiwan.

Madsen, S.F. 1994. Provenance trial of Abies nordmanniana and Abies bornmülleriana for Christmas tree production in North Sealand. For. Landscape Res. 1(2): 143-166.

Nielsen, U.B. and G.A. Chastagner. 2005. Variation in postharvest quality among nordmann fir provenances. HortScience 40(3):553-557.

Owen, J.H. 2005. Selecting sites for fraser fir production. North Carolina State Univ. Coop. Ext. Christmas Tree Notes CTN-036.

Potter, K.M., J. Frampton, S.A. Josserand, and C.D. Nelson. 2010. Evolutionary history of two endemic Appalachian conifers revealed using microsatellite markers. Conserv. Genet. 11(4):1499-1513.

Quesada-Ocampo, L.M., D.W. Fulbright, and M.K. Hausbeck. 2009. Susceptibility of fraser fir to Phytophthora capsici. Plant Dis. 93(2):135-141.

Shew, H.D. and D.M. Benson. 1981. Fraser fir root rot induced by Phytophthora citricola. Plant Dis. 65(8):688-689.

Talgø, V., M.L. Herrero, B. Toppe, S.S. Klemsdale, and A. Stensvand. 2007. Phytophthora root rot and stem canker found on nordmann and subalpine fir in Norwegian Christmas tree plantations. Online. Plant Health Prog., doi: 10.1094/PHP2007-0119-01-RS.

Tompkins, D. 2000. Looking forwardViews from the Northeast. Amer. Christmas Tree J. 44(1):12-15.

U.S. Department of Agriculture. 2009. Census of horticultural specialties. Vol. 3. Part 3. U.S. Dept. Agr. AC-07SS-3.

Williams, R. 2002. Evaluation of the competitive position of the fraser fir Christmas tree. 1 Apr. 2012. <http://www. ncagr.gov/stats/crops/ChristmasTree Buyers2001.pdf $>$. 